University of Chicago Law School

Chicago Unbound

Journal Articles

Faculty Scholarship

1967

\title{
The Empty Cabinet of Dr. Calabresi - Auto Accidents and General Deterrence
}

Walter J. Blum

Harry Kalven Jr.

Follow this and additional works at: https://chicagounbound.uchicago.edu/journal_articles

Part of the Law Commons

\section{Recommended Citation}

Walter J. Blum, Harry Kalven \& Jr., "The Empty Cabinet of Dr. Calabresi - Auto Accidents and General Deterrence," 34 University of Chicago Law Review 239 (1967).

This Article is brought to you for free and open access by the Faculty Scholarship at Chicago Unbound. It has been accepted for inclusion in Journal Articles by an authorized administrator of Chicago Unbound. For more information, please contact unbound@law.uchicago.edu. 


\title{
The Empty Cabinet of Dr. Calabresi* Auto Accidents and General Deterrence
}

\author{
Walter J. Blum and Harry Kalven, Jr.
}

"If Yale is against us, who will be for us?"

C. O. Gregory

The notable renaissance of writing about auto compensation plans in the past few years calls for a strong reason for adding still another essay to the stream. ${ }^{1}$ In his article last year in the Yale Law Journal, ${ }^{2}$ Professor Calabresi has prodded us, we believe, with two such reasons. First, he has been so effectively witty in reviewing our own position as put forth in Public Law Perspectives on a Private Law Problem ${ }^{3}$ that under the stern conventions of academic gamesmanship we are im-

Walter J. Blum, Professor of Law, The University of Chicago, received a B.A. degree in 1939 and a J.D. degree in 1941 from the University of Chicago.

Harry Kalven, Jr., Professor of Law, The University of Chicago, received an A.B. degree in 1935 and a J.D. degree in 1938 from the University of Chicago.

- It might be noted at the outset that at least three of our colleagues mistakenly claim credit for this title. Once again we wish to acknowledge that we have benefited greatly from discussions with Harold Demsetz of The Graduate School of Business, University of Chicago. There remain several points of disagreement between us, perhaps suggesting that we have not yet benefited enough from his advice.

$\dagger$ Personal letter, dated $6 / 6 / 66$, to Harry Kalven, Jr. The letter is no longer on file.

1 The principal writings during the past three years, in addition to those of Calabresi, collected infra note 4, include Keeton \& O'Connell, Basic Protection for the Traffic VICTIM (1965), which contains an extensive bibliography at pages 543-66; CoNARD, Morgan, Pratt, Voltz, \& Bombatgh, Automobile Accinent Costs and PaymentsStUdies IN THE Economics of INJURY Reparations (1964); Conard, The Economic Treatment of Automobile Injuries, 63 Mich. L. REv. 279 (1964); James, An Evaluation of the Fault Concept, 32 TENN. L. REv. 394 (1965).

For two especially relevant pieces by economists, see Demsetz, The Exchange and Enforcement of Property Rights, 7 J. L. \& EcoN. 11 (1964); Rottenberg, Liability in Law and Economics, 55 AM. ECON. Rev. 107 (1965).

There has also been an exceptionally important and lively book review "literature" on the various books involved.

2 Calabresi, Fault, Accidents, and the Wonderful World of Blum and Kalven, 75 YAIE L.J. 216 (1965).

3 Blum \& Kalven, Public Law Perspectives on a Private law Problem-Auto Compensation Plans (1965); Blum \& Kalven, Public Law Perspectives on a Private Law Problem-Auto Compensation Plans, 31 U. CHI. L. REv. 641 (1964). 
pelled to reply. But more important, in focusing on the auto accident problem he has crystallized the economic analysis of liability which he has been developing in his writings over the past several years. ${ }^{4}$ The analysis deserves careful attention because it may have a reach far transcending the auto problem and because, although couched in the idiom of superior risk bearing, it strikes us as saying something quite new for the legal discussion.

It is a tribute to Calabresi's rhetorical skill that he manages both to kid us for being in the wonderful world of classical economics and to criticize us for favoring an extension of social security to cover auto accident victims. Seeing how he got there will serve to throw light on the soundness of his analysis generally.

Our earlier essay was occasioned by our feeling that, although auto compensation plans were popular among academic commentators, the arguments offered on behalf of them lacked rigor. Indeed, it had never been clear why anyone would oppose what was made out to be such a totally desirable reform. The argument for a plan was that it would eliminate the costs and delays of litigation under the fault system, and that it would provide prompt, adequate compensation for all victims. What we had hoped to do was point up that the issue was not that simple: there was an inescapable countervailing factor. The increased number of victims covered with compensation under a plan would necessarily entail additional costs. Therefore the pivotal question about a plan, to us, was how these additional costs would be met. We were not persuaded that they could be met by the increased efficiency of administering a plan as compared to the common law system; we were not persuaded that they should be met by a lowering of damage awards across the board; and we concluded that it would be impractical to compel the victims to insure themselves by buying first party insurance. We therefore confronted the alternative that the additional costs should be absorbed by the motorists. Here again, even after a detour into economic analysis, we were unable to locate a satisfying rationale for charging the motorists.

In the end we felt that the fault liability system was not indefensible and that it should be retained until a better touchstone had been found to guide in allocating the necessary additional costs of a plan.

4 Calabresi; Some Thoughts on Risk Distribution and the Law of Torts, 70 YALE L.J. 499 (1961); Calabresi, The Decision for Accidents: An Approach to Nonfault Allocation of Costs, 78 HARv. L. Rev. 713 (1965); Calabresi, Fault, Accidents and the Wonderful World of Blum and Kalven, 75 YALE L.J. 216 (1965) [hereinafter cited as Calabresi]. 
We saw the problem as a hard choice between less than satisfactory alternatives. We could stay with our present system; or we could move to a plan at the price of arbitrarily allocating the costs to motorists via higher insurance premiums, or to victims via lower awards, or to some combination of both. ${ }^{5}$ We submitted, however, that if the value of having all victims compensated was paramount, that goal could best be achieved by extending social security. This view seemed especially cogent for those concerned about human misfortunes, since there is nothing distinctive about the misfortune of being hit by an automobile.

The Calabresi critique moves on different levels. The broadest line of attack is that we display a basically unsound approach to issues of law and public policy, and that this flaw-more than any specific weakness in our analysis of the auto accident problem-brings us out with the wrong answer. There are, he would emphasize, a multiplicity of goals to be served by the law in this area. No single alternative will in an imperfect world achieve them all satisfactorily. Sound policy judgment therefore seeks the legal measure that will achieve the best mix among the goals. ${ }^{6}$

When applied to the auto accident problem, his multi-goal analysis runs like this. There are three main legal measures: the common law fault system, a compensation plan paid for by motorists, and social security financed out of general tax revenues. Further, there are several goals for the law here: justice (which he professes not to understand and largely dismisses); compensation of the injured; wide distribution of costs so as to avoid the impact of jarring losses; and holding to a minimum the net waste of resources for society-that is, bringing accident-associated costs to an optimal level. Calabresi never quite shows us his scorecard; but there is a strong intimation that had we tested the fault system against the mixture of goals, as he argues we should have done, it would have finished a poor third..$^{7}$ It is not superior in the achievement of any of the goals, and it is admittedly infe-

5 In our earlier piece we emphasized that there is no simple way of contrasting the present fault liability system with motorist compensation plans because of the variety of possible plans and because of the variety of common law rules. Only in a rough sense is the difference captured by the opposition between fault liability and strict liability. BLUM \& Kalven, op. cit. supra note 3 , at 4 .

6 "The second problem is that Blum and Kalven reject most proposed 'plans' because they do not do as good a job of meeting a specific goal as an extreme or ideal solution; but these plans are never examined as ways of accomplishing a complex mixture of goals. Each plan is rejected because it does not do perfectly some one thing we desire, although it may do the combination of things we want pretty well." Calabresi 221.

7 "And the key question, whether fault or any given non-fault system best accomplishes the mixture we in fact want, is never really askedl" Ibid. 
rior in providing compensation. ${ }^{8}$ The motorist compensation plan is also not superior when measured separately against each goal; but since in each of these ratings it is never the poorest, always being at least second best, it emerges as the overall soundest solution.

If all that Calabresi means is that one should weigh the various competing considerations in reaching a policy conclusion, no one would ever disagree. But he seems to be saying something more precise, to have developed his own Occam's razor for assessing issues of public policy: achieving two goals is always better than achieving one. Whether or not he meant to be so flat footed about it, there are pitfalls in being schematic about the goals of law. It is not easy to locate what the goals of a law are. Nor is it easy to know when we can properly split one goal into two. And it cannot be assumed that all goals are of coordinate importance. Often the achieving of one important goal will outweigh the achieving of two lesser goals. For all these reasons any apparent quantification is likely to be illusory.

In our specific case of the auto compensation plan, multiple goal scoring turns out to be especially awkward. It is symptomatic of the difficulties that Calabresi is reluctant to keep justice in as a goal and constantly professes to find the concept unintelligible. ${ }^{9}$ If one looks only to the benefit side or aspirations of almost any welfare scheme, surely the scheme will appear attractive. In large part what tension there is in debate over such policies will arise over the justice issuethe question of how the costs of the measure are to be met. We submit that the avoidance of injustice or arbitrariness in allocating costs is also a goal; moreover, it is a goal likely to conflict with the other goals put forward. And the slipperiness of multiple goal quantification is nowhere better seen than when one attempts to score a proposal by whether it was gloriously just, tolerably just, tolerably unjust, or just plain lousy. If a proposal fails to satisfy a sense of justice in the allocation of its costs, it will, we suggest, be decisively impeached regardless of how fully it may achieve its other goals.

Initially, we had urged that the only critical question to be answered

8 It is inferior in the sense that by the very nature of the fault criterion, not all victims will be able to shift their losses.

9 "The fact is that to varying extents we all want our laws dealing with automobile accidents ... to satisfy certain 'justice' and 'revenge' requirements (some of which are undifferentiated and some of which are for me just plain unintelligible) ...." Calabresi 238. Compare, however, the somewhat different reaction of Holmes: "The undertaking to redistribute losses simply on the ground that they resulted from the defendant's act would not only be open to these objections, but, as it is hoped the preceding discussion has shown, to the still graver one of offending the sense of justice." Holmes, The Common LAw 96 (1881). 
with respect to auto compensation plans was how they were to be paid for. When the dust has finally settled on the multiple goal analysis, the critical question remains unchanged. This perhaps explains why Calabresi does not rest his case with the multiple goal rhetoric but acknowledges a responsibility for justifying the allocation of the additional costs to motorists.

\section{II}

Before turning to what Calabresi argues is the economic justification for assessing the costs against motorists, we must pause briefly for another unusual rhetorical ploy in his article. ${ }^{10}$ The question before the house in our earlier essay was whether a compensation plan was sufficiently superior to the common law system to justify a shift. Calabresi's answer is a firm yes-because a compensation plan is superior to social security!

His conclusion rests on a general economic insight with which we agree. A possible weakness of social security is that it takes the costs of auto accidents off the participants and places them on taxpayers indifferently. The result is that whatever pressures toward safety there might have been on the participants because of their sensitivity to bearing some part of the costs of accidents are eliminated. To use Calabresi's idiom, social socurity "externalizes" from the activities that produce accidents the costs of those accidents-bringing in its wake a loss of "general deterrence."

What is arresting here is not the content of his economic analysis, but rather his feeling that the point about externalization of costs under social security virtually disposes of the basic issue about auto plans. Surely, members of the bar and bench, who are bracing themselves for debate, see the choice as between the common law system and the various forms of compensation schemes, including social security. Yet Calabresi is quite serious in asserting that this misframes the issue. He is persuaded that the compensation shortcomings of the common law system are too great to be tolerated much longer by society. The wave of the future therefore will bring a compensation scheme in some form, and at this time the only policy issue for sensible men to debate is what that form should be.

What disturbs us is that Calabresi achieves the appearance of having won the case against the common law system by making a point of economic analysis. But in fact what he has done at most is to win a case against social security by his economic point and then to claim a

10 See especially Calabresi $219-22$. 
win by default against the common law system on the basis of a political hunch.

Nor is this quite all. There is at least an implication that by scoring on economic grounds against the social security system he has also scored on economic grounds against the common law system. Although he is careful and in full command of the analysis, his emphasis obscures the point that externalization of costs-the economic shortcoming of social security-does not carry over to the common law system. It too avoids externalizing costs. The comparison in economic terms of a motorist compensation plan and the common law system is a far more subtle and difficult matter than is the comparison of a motorist plan and social security.

As a means of providing compensation, a social security approach has the great merit of admitting of a candid rationale for who should bear the cost of the benefits and a coherent rationale for who the beneficiaries should be. It can, that is, provide an open weighing of costs against benefits and a clear test of the depth of the public consensus on welfare measures. One can therefore only wonder how heavily Calabresi would under other circumstances weigh the loss of general deterrence involved in social security. If we already had auto accidents under social security, would Calabresi then be disposed to argue that they should be taken out and handled separately under a compensation plan financed by motorists? And further, would he say the same about victims of motorboat or bicycle accidents? ${ }^{11}$ In these instances, too, social security would externalize the costs of the accidents and would eliminate whatever inducement the bearing of these costs might have on the participants to reduce the loss from accidents. Surely there are limits to the attractiveness of atomizing social security in the quest for general deterrence.

\section{III}

Near the end of his article, ${ }^{12}$ Calabresi does address himself directly to what we have urged is the central issue about compensation plans: What is the rationale for charging the new costs against motorists? The justification is to be found, he suggests, in utilizing the criterion of general deterrence. By way of preface to the argument, we pause for a look at the general deterrence thesis in the large.

11 It is tempting to add victims of lightning, lung cancer and bathtub tumbles. However, there is a difficulty in devising a compensation plan which is an alternative to social security. Compare Calabresi, supra note 4, 78 HARv. L. REv. at 715. See text accompanying notes 71-73 infra.

12 Calabresi 231-37. 
There is for the law world a certain freshness about the Calabresi analysis. Although focusing on deterrence, he is not working over old notions about the use of sanctions to discourage antisocial behavior; ${ }^{13}$ he would distinguish sharply between specific deterrence, which has been the traditional hope of the law, and general deterrence, which is for him the new hope for the law borrowed from economics. Moreover, while building his liability theory on economic analysis, he relies very little on the idea of a wide distribution of losses which has been so fashionable in other economics-oriented legal commentary. ${ }^{14} \mathrm{His}$ concern is rather with the allocation of costs, including accident losses.

The law has not been a complete stranger to the concern with allocation of costs. For the most part in a market society with private property, the allocation of costs is noncontroversial and appears to be automatic. The cost of steel in buildings constructed of steel, for example, is reflected without controversy ${ }^{15}$ and without the intervention of law other than to protect the market institution. When the allocation of costs has appeared controversial, there usually have been direct intrusions into this process by way of governmental subsidies or special taxes not designed to raise revenues. In the subsidy situation, part of the cost

13 See, e.g., Gregory \& Kalven, Cases on Torts 690-702 (1959); Morris, Punitive Damages in Tort Cases, 44 HaRv. L. REv. 1173 (1931).

14 It would be a worthwhile task to write the intellectual history of economic ideas in tort liability theory, beginning perhaps with Holmes' remark that "The state might conceivably make itself a mutual insurance company against accidents and distribute the burden of its citizens' mishaps among all its members." Holmes, THE CoMmon LAW 96 (1881). In rough profile, the ferment begins with the debate over workmen's compensation legislation at the turn of the century, when it is argued that the costs of industry should be placed on industry. A decade or so later Laski, Smith, and Douglas seek to rationalize vicarious liability rules by analogy to workmen's compensation. The point changes somewhat, the emphasis being placed on the wide distribution of losses through use of the market mechanism and liability insurance, and the phrase "enterprise liability" is exploited. After the passage of another decade or two, tort scholars, in particular James, Morris, Ehrenzweig, and Green, attempt to adapt the agency analysis to tort liability rules. Again the emphasis changes slightly, and the concern is with the customary patterns of carrying insurance and relative accessibility to insurance. The quest is for the "superior risk bearer." Finally, in the current decade the stimulus to use of economics is found mainly in the auto compensation discussion.

In his earliest essay, supra note 4, 70 YALE L.J. at 499 (1961), Calabresi differentiates the various economic ideas behind the phrase "risk distribution." His focus is not primarily on achieving wide distribution of losses. What is distinctive about his approach, although there are faint echoes of it in the writings of Douglas, is his attention to the possibility of changing behavior so as to reduce the net loss to society from accidents.

15 Perhaps this isn't such a good example after all. See Youngstown Sheet \& Tube Co. v. Sawyer, 343 U.S. 579 (1952), discussed in Kurland, Guidelines and the Constitution: Some Random Observations on Presidential Power to Control Prices and Wages, in Shultz \& Aliber, Guidelines, Informal Controls and the Market Place 209 (1966). 
would have been shifted from the users of steel buildings to the taxpaying public; in the tax situation, costs would have been added to the users of steel buildings. In both cases the objectives are clear: in the one it is to encourage the use of steel in buildings; in the other it is to discourage it. All this is, of course, very familiar. But the point to be stressed is that for the economist cost is instrumental, and the allocation of it always reflects some government policy. There is nothing more "natural" in having the users of steel buildings bear the cost of steel than there is in having the tax-paying public bear that cost. The choice simply defines the nature of the society and its institutions.

The destruction of persons or property in the course of some activity is also a cost. The allocating of these costs has been a basic concern of law and liability theory, and the traditional legal formulas for allocating the costs of accidents have been embodied in the rules of torts and agency. ${ }^{16}$ When the lawyer turns to the economist and asks that he evaluate these rules in cost allocation terms, the discussion is likely to be at cross purposes. The lawyer hopes to be told about "proper" or "improper" allocation of costs; the economist can only repeat that these costs, like all costs, are instrumental, and therefore he will ask the lawyer what purposes he wishes to achieve in allocating them.

Calabresi is very clear about all this. ${ }^{17} \mathrm{He}$ sets out a purpose he wishes to achieve in allocating the costs of auto accidents to motorists. His goal is to optimize the costs of auto accidents to society, and he proposes to do so by utilizing what he thinks are the possibilities for general deterrence which can be exploited by placing liability costs on motorists. Although in theory we today might have either too much or too little general deterrence pressure, Calabresi proceeds on the assumption that we have too little because no part of losses in non-fault accidents is now charged against motorists. Thus he assumes that moving toward optimization of costs calls for reducing the number of auto accidents. ${ }^{18}$

An extended illustration of how liability law can be made to serve the objective of general deterrence is needed at this point. Whatever the economist's phrasing, what is being discussed is human behavior and ways of changing it. To put the problem in a formal way, for liability law the choice is between placing liability for a loss on Group

16 HoLmes, THE COMMON LAW 77-79 (1881).

17 See, e.g., Calabresi, supra note 4, 78 HARv. L. REv. at 725.

18 "[N]on-fault plans would, in fact, give better deterrence than fault, because they would tend to deter activities prone to serious accidents rather than just activities prone to fault-caused serious accidents." Calabresi 222 n.14. See also the discussion infra, Part V, on optimizing auto accidents. 
A or leaving the loss on Group B upon whom it initially falls. In general deterrence terms, there is only one argument for imposing liability on Group A: we should do so if the behavior of Group A and of Group $B$ will be different than when we leave the loss where it falls, and if this difference in behavior will reduce the net loss to society.

The tracing of such behavioral consequences can be quite complex. To use again an illustration from our earlier essay, we will assume that Group A are manufacturers of a watch with a radium dial that will cause distinctive skin damage to some users. The policy issue is who is to bear the cost of the skin damage-the manufacturers or the users, who as a class can be looked upon as Group B. The situation thus posed looks promising for various strategies of reducing the net losses from skin damage. Without working through these exhaustively, attention should be called to the possibilities that a substitute product not having radium on the dial might be developed, that a shield might be designed to protect against skin irritation, or that users might change their habits of wearing the watch continuously so as to reduce the hazards of exposure. Several things should be noted. None of the behavior listed has yet occurred, but is merely a future possibility. Each will represent a net gain in productivity to society so long as the cost of it does not exceed the reduction in losses it can effect. Further, independent of liability law there are strong motivations present to come up with safer products. Economic self-interest suggests that there must already be a race among manufacturers to develop a safer watch, especially when we look to the competition from substitute products. It would thus be a pretty fair prediction that sooner or later one of these possible lines of improvement will materialize, whatever the law does or does not do about the liability problem.

What Calabresi must show here is that the process will go faster ${ }^{19}$ -that the motivations toward safety will be deepened-if the law intervenes by placing liability on the manufacturers. And indeed he sketches what could be a plausible case in this situation..$^{20}$ By making the manufacturer liable for all such losses, the law forces him to become aware of his recurring experience with the loss. Being an enterpriser he presumably can also calculate the costs of any given "remedy." The result is that he should be in a position to make a calculus of safety versus cost. Moreover, at least in the short run, it will be to his economic advantage to innovate safety measures that, by reducing his li-

19 Once again the assumption is that we have too many accidents and too little investment in safety. Conceivably, the economic calculus might call for slowing down the investment in safety.

20 Calabresi 224-31. 
ability losses, will reduce the net costs of his operations, and thereby increase his net profit.

Assuming that the strategy of holding the manufacturers liable will induce them to seek out desirable safety measures, are there offsets in the motivation of users to minimize injuries? While they can now shift the loss of skin damage back to the manufacturer, it would seem that on balance the positive impact on manufacturers will be greater than the negative impact on users. The users are not centralized; they are unlikely to have technical expertise; they are less likely to perceive the incidence of damage; and for the individual user, the cost of seeking alternatives must outweigh the advantage to him. Whether the losses are left on users or are shifted off of them is not likely to make a perceptible difference in their behavior.

From the viewpoint of general deterrence there is another advantage in placing liability on the manufacturer, an advantage which is paradoxical from the perspective of the common law. ${ }^{21}$ If liability is placed on the manufacturer by law, the accepted economic analysis is that through the operation of market forces this additional cost on the producer ultimately will be passed on to the users in the form of increased prices. ${ }^{22}$ Whichever way the law jumps here, the users of radium dial watches as a class will end up bearing the cost of losses from skin damage; yet there is a gain in having the loss placed on the manufacturer and shifted back to the users. ${ }^{23}$ The point is that the individual user is more likely to perceive the increase in his purchase price than to perceive his share of the risk of skin damage. In this sense he is more accurately confronted with the costs of using radium dial watches and gets to cast a more intelligent consumer vote. As a result, any "over consumption" of radium dial watches due to unawareness of the true costs of using them is eliminated.

We have dwelt at some length on this example to give a "feel" for the subtleties of the behaviorial analysis on which general deterrence theory rests. In the radium watch situation we think it is likely that a

21 We noted the paradox in our earlier essay, BLUM \& KALVEN, op. cit. supra note 3, at 60 .

22 Due to time lags, monopolies, and lack of perfect knowledge, the passing on of costs through increased prices will often be less than perfect. See Calabresi, supra note 4, 70 YALE L.J. at 499.

$23 \mathrm{We}$ confess error here. In our earlier essay we overstated the degree to which consumers would have knowledge to propexly assess the risks of radiation injury. We failed to take our assumption of "perfect" knowledge to its logical terminus. Calabresi has now done so at our expense, giving point to his "Wonderful World" title. Calabresi 228. 
case can be made out for placing liability on the manufacturer. ${ }^{24}$ Perhaps a vague perception of such a general deterrence calculus is at the source of the contemporary revolution in products liability law. ${ }^{25}$ This is not to say that a case for general enterprise liability to consumers has been established regardless of context. Consider, for example, the commercial airline. Motivation of the airline enterpriser to seek out safety may already be so close to optimum that change in liability law could not be justified by the argument that it would make a difference in behavior.

There is one final characteristic of the radium watch dial type of case that needs to be underscored. It is seen that the choice here is not ultimately between placing the loss on the consumer or relieving him of it; it is rather between placing the loss on him by one method or by another-either by leaving the loss on him initially or by shifting it to the manufacturer via liability rules in the expectation that it will be shifted back to the consumer via market forces in the form of increased prices. ${ }^{26}$ In this special context even a slight advantage in general deterrence may be persuasive. The strains on general deterrence analysis, however, may be considerably greater when the choice is whether or not to place the costs on a group that would not otherwise bear them.

IV

We must acknowledge that Calabresi has not as yet attempted to make a complete analysis of the possibilities for general deterrence in the auto accident situation. He has only argued that the possibilities are promising enough to call for careful consideration of them in any policy decisions about the auto problem. We propose here to attempt to think through in some detail where the pursuit of general deterrence in the auto case might lead. In thus going beyond the analysis Cala-

24 The facts in the radium watch dial example have been kept overly simple by assuming that the radium on the dial is the only cause of the particular skin disease. In the real world, complications about causation may make it difficult to isolate the contribution of the product from the contribution of the other possible causes of the particular harm, thus making it arbitrary to shift such losses to the manufacturer. Consider the current problem of lung cancer and cigarette manufacturers.

25 See Kalven, Torts: The Quest for Appropriate Standards, 53 CALIF. L. REv. 189, 205-06 (1965); RESTATEMENT (SECOND), TORTS \& 402A (1965) (suggesting a possible limit in the revolution in tort liability for injurious products).

26 Because the parties are in a position to bargain with each other, there is another possibility. The manufacturer could give the consumer a choice of buying the product at a lower price without recourse against the manufacturer for harm or of buying at a higher price which reflects the manufacturer's strict liability for harm. Arguably, this arrangement has the advantages of the other possibilities without their disadvantages. It maximizes consumer choice and nevertheless confronts the consumer with "proper" prices. But see Calabresi 225-30. 
bresi has so far offered on general deterrence, we run the risk of committing some errors in its name.

Since we presumably are talking about a change in the existing law, that law provides the baseline against which any gains in general deterrence have to be measured. The law now places the cost of negligently caused accidents on motorists and does so on the theory that motorists are having accidents a reasonable man would not have had. A proposal to place all costs on motorists on general deterrence grounds must therefore seek its justification in the likelihood that such an allocation of costs will reduce the accidents that even a reasonable man would otherwise have had, and will do so without excessive offsetting costs. ${ }^{27}$ To state the matter this way suggests that to establish the general deterrence thesis in respect to auto accidents will be something of an uphill fight.

There are other reasons why the auto field may prove an unfertile one for a general deterrence approach, both of which become apparent when we compare the auto case to the radium dial watch case. That there may have been a valid reason for placing all accident costs on the watch manufacturer does not establish a comparable reason for placing all accident costs on motorists. In very large part the cost savings that were expected to be achieved in the watch situation depended upon two circumstances. First, the manufacturer as an enterpriser is presumably in a position to make an economic calculus both about the probability of accidents from the watches and about the cost of alternative means of reducing them. He can therefore be expected to invest in safety up to the appropriate degree. Second, since as a result of market forces the consumer will in the end inevitably bear the cost of accidents from the watches, it is desirable to place him in a position where he will confront and recognize these costs as directly as possible, and will regulate his purchases accordingly. Neither of these points holds for the auto case. The driving of autos is not basically a business; and, as we shall see, it is far more difficult for the individual driver to make an economic calculus of accident losses and accident risks. Moreover, the decisive fact about auto accidents is that market forces do not inexorably place the costs of these accidents on any group. If the law elects to leave them on victims, they will be left on victims. If the law elects to place them on motorists, they will remain on motorists. ${ }^{28}$ There is therefore no point in talking about confronting any

27 "Tt is sometimes said that the study of negligence is the study of the mistakes a reasonable man might make." Gregory \& Kalven, CasES ON TORTS 89 (1959).

28 Theoretically there is one conceivable qualification: the parties in a limited number of instances might strike private bargains and shift the loss. See note 53 infra. 
group with the costs of auto accidents on a theory that such a confrontation makes explicit to them what they must bear in any event.

Since the costs will not fall on motorists through the operation of market forces but will do so only if the law decides to place them on motorists, it may be useful to conceive of the issue as if it were one of taxation. The question is: Should motorists be taxed to pay for all the losses suffered by auto accident victims? We would agree with Calabresi that a case for such a tax might be made if it can be shown that once the levy is imposed the behavior of motorists and potential victims will be so altered that there will be a significant improvement in achieving an optimum number of auto accidents for society as a whole.

As far as we can see, there are just three routes through which general deterrence can be expected to operate on auto accidents. It can lead to the discovery of safety devices or techniques. It can induce an improvement in driving habits. It can cause a discriminating reduction in the level of driving and a substitution of safer activities in place of driving. As Calabresi has summarized the prospects: "we may, if we are made to pay for car-caused accidents, drive less, or less at night, or less when we are of accident-prone ages, or with more safety devices than if we are not made to pay for accident costs when we decide to use a car." ${ }^{29}$ And he adds: "I call this thesis general deterrence, because it seeks to diminish accident costs not by directly attacking specific occasions of danger, but (like workmen's compensation) by making more expensive those activities which are accident prone and thereby making more attractive their safer substitutes." 30

It may be true, as James and now Calabresi have argued, ${ }^{31}$ that the advent of workmen's compensation did provide a stimulus for discovery of safety measures for coping with the industrial accident. But even if this reading of a complex history is correct, it does not help us much in tracing through why taxing motorists will lead to the discovery of safety measures for coping with the auto accident. The theory must be that motorist-consumer awareness of accident costs will create an increased demand by them for safer cars, thus putting the pressure on manufacturers to increase their level of innovation concerning safety features in autos. This sequence of behavior seems quite unpromising in view of the long history of consumer unwillingness to pay

29 Calabresi 223.

30 Ibid.

31 James, Accident Liability Reconsidered: The Impact of Liability Insurance, 57 YALE L.J. 549 (1948). 
for safety in the purchase of autos. ${ }^{32}$ In any event, if one is serious about taking this route, it might make more sense to place the costs on manufacturers of autos directly. ${ }^{33}$

As an aid to analysis, we proceed to test our reactions to an auto compensation plan which imposes strict liability on the manufacturer for all accidents involving its cars. Let us assume that this "plan" would be appropriately qualified to take account of various outrageous accidents, such as those caused by drunken driving of old, secondhand, beatup cars. The auto case might then be seen as in line with the radium watch case or workmen's compensation-that is, there would be economic pressure put on the manufacturer, and these costs would be passed on to motorist-consumers via the market. Some intractable difficulties remain, nevertheless. It appears likely that a majority of accidents are traceable to the driver and not to the car. ${ }^{34}$ Certainly this

32 However, consumer interest in safety appears to have increased during the past year. See NAder, Unsafe at ANy SPefd (1965); O’Connell \& MYers, SAfetr Last (1966).

33 Our purpose in positing a plan which puts accident costs on auto manufacturers is only to test the strongest case for the Calabresi analysis. We recognize that there may be a new disadvantage introduced in limiting the freedom of choice of car purchasers. See note 26 supra.

34 Fifteen years ago James and Dickinson reported that only $31 / 2$ per cent of the cars involved in accidents had mechanical defects, and only in $1 / 4$ of 1 per cent of the accidents were they thought to be a contributing factor. James \& Dickinson, Accident Proneness and Accident Law, 63 HARv. L. Rev. 769, 770 (1950).

Our colleague, Hans Zeisel, has advised us as follows regarding the contribution of mechanical defects to auto accidents:

"Just how many accidents are caused by mechanical defects of the automobile-that is, how many accidents would not happen if the defect had not existed-is an unknown figure. Only one research design could reveal it, and that design has never been used. It calls for taking a random sample of accidents, and then ascertaining for each accident all the facts, including a sufficiently thorough examination of the car or cars involved. This research design is feasible; the experts for it are available; but it is costly because it would often involve stripping a car beyond the needs of immediate repair.

"The paradigm of such a research design was developed many years ago in a study sponsored by the United States Department of Commerce:

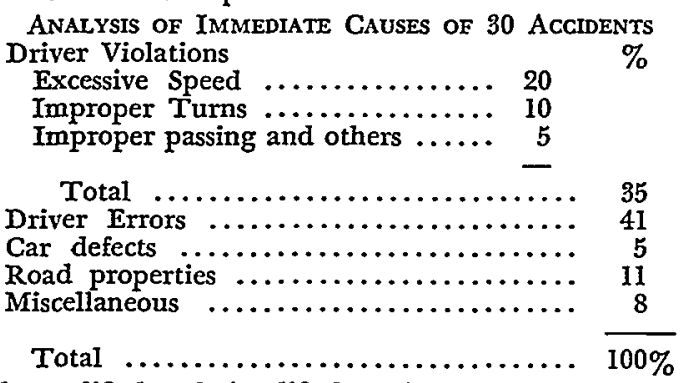

"This is a slightly modified and simplified version of a table reproduced in H.R. Doc. No. 462, 75th Cong., 3d Sess. Il (1938). Unfortunately, this study was not based on a representative sample, nor was the mechanical examination of the cars sufficiently thorough. 
kind of major change in liability policy ought not be predicated on the futuristic possibility of a driver-proof car. Even when we acknowledge, as we must, that changes in construction and design will have a greater impact on the gravity of accidents than on their incidence, ${ }^{35}$ it seems that the possibility of reducing auto accidents in major part falls beyond the reach of this strategy.

Further, it is well to recognize what we are talking about. The objective is to encourage inventiveness, research, discovery. And what are sought are not safer devices simply, but safer devices which are roughly the economic equivalent of those now in use. It is true that placing economic pressure on the manufacturer works in the right direction. But if we are willing to tax on behalf of this objective, we confront the difficulty that there are alternative ways of stimulating such research that might well be more effective dollar for dollar. We might, for example, utilize government subsidies of research laboratories and perhaps a scheme of honorific government prizes. But whatever might be the best technique, once the quest is avowedly for stimulating inventiveness it is no longer clear why motorists alone are the proper group to call upon to pay for the stimulus.

In the end, the strategy seems to come down to this: motorists, who on hypothesis are driving cars that could have been built safer, are to be made to pay for the losses from accidents caused by those cars in the hope of inducing someone else to be more inventive or persistent about designing safer cars.

\footnotetext{
"In recent years several approximations to the suggested research design have been achieved. The Swedish government, through one of its agencies, undertook such a study, but only for single car accidents-accidents that involve no collision with another car. While the report on this study has not been made available, upon informal inquiry the figure for mechanical causation, including tire failures, was tentatively placed around 25 per cent. In evaluating this finding one must keep in mind that mechanical failures are probably higher in single car accidents than in collisions, and that conditions in Sweden might differ from those in the United States.

"Another study based on a random sample of accidents was done in upstate New York, but it was limited to determining the part alcohol played. Autopsies were performed on some one hundred consecutive death casualties in auto accidents; some fifty per cent were found to be inebriated beyond the legally allowed alcohol limit.

"Another such partial assessment study concerning the contribution of faulty tires in a random sample of auto accidents is now under way at the Traffic Institute of Northwestern University under the direction of J. Stannard Baker, who was also responsible for the United States Department of Commerce study reported above."

One could get to a logical problem in deciding when an accident is caused by the driver or is caused by a defect in the car. A good driver, knowing he has bad brakes, might be able to adjust his driving pattern so as to take account of the defect. Presumably the reported statistics are based on much cruder notions of defects and causation.

35 See Katz, Liability of Automobile Manufacturers for Unsafe Design of Passenger Cars, 69 HARv. L. REv. 863 (1956); Noel, Manufacturer's Negligence of Design or Directions for Use of a Product, 71 YALE L.J. 816 (1962).
} 
One final point of perspective might be added. Once a safety discovery has been made and has become economically feasible, the compulsion of an accident compensation plan is not required to bring it into use. The existing law is capable of quite quickly absorbing the change as a matter of the common law calculus of negligence; and if that is thought too slow a process, society can always turn to specific safety legislation.

The second route for general deterrence in the auto case is one that sounds more familiar to the legal ear. It is that we might by law change the conduct of motorists. No one doubts that an enormous reduction in auto accidents would be effected if we could devise some way of altering the habits of motorists. The theory, although Calabresi does not seem to rely on it, must be that by imposing the "liability tax" on those involved in auto accidents without regard to fault, we can make them more sensitive to the connections between their driving behavior and the accidents, and thus induce a change in their habits. Since the law already imposes on them the obligation to drive with reasonable care, the hope here is to induce what might well be called super-care. In brief, the thesis is that economic pressures may be able to mould conduct better than law using criminal fines, license suspensions, and tort liability keyed to negligence. The target at this point in the analysis is not the more effective screening of potential drivers, but rather the interstitial improvement in the behavior of those who are already driving. ${ }^{36}$

At the threshold this approach runs into a major obstacle. It is surely commonplace knowledge that any driver is always risking not simply the safety of others, but equally his own personal safety. Inasmuch as the situation thus already seems to present a very high inducement to safety, it is hard to see what additional incentive to super-care will be added by economic pressure.

If we go on to assume that there may be some people who would react to the change in costs, there are some less obvious difficulties to consider. There is the circumstance that any motorist compensation plan will operate through use of auto insurance. The economic pressure or tax we seek to impose consequently will appear in the form of premiums. In turn this means that the premiums will have to be differentiated so as to show the individual motorist that if he engages in super-care, he will be rewarded by a smaller premium. Just how one

36 For clarity of analysis we distinguish here between the objective of improving the behavior of those who drive and the objective of dissuading riskier drivers from taking the wheel. The general deterrence theory aspires to achieve both objectives simultaneously. The second objective is discussed later. 
does this is not clear. Presumably, since we are not going to introduce the fault system all over again in order to graduate insurance premiums, the allocation will be on the basis of some test such as involvement in accidents. If the motorist understands that this is the way premiums are graded, he may learn the wrong lesson or be discouraged when he realizes that, no matter how careful he is, he will not get his "reward" if he is the victim of another's carelessness.

But beyond this, there is a further sense in which the motorist's fate is linked to the behavior of others. The nature of insurance requires that we deal with classes of persons representing different degrees of risk. Any one motorist is therefore stuck with a kind of guilt by association. The extent to which he gets his premium adjusted downward for his super-care always turns in part on the incidence of accident involvement by strangers.

These difficulties are no surprise. They reflect those characteristics of insurance which critics of the current common law system have pointed to in arguing that, because of the dilution of impact due to insurance, even the fault system does not deter. ${ }^{37}$ Further, if some way of making auto insurance a more discriminating mechanism among insured motorists could be devised, there is nothing that would keep us from using it under the existing system of negligence law without waiting upon a compensation plan.

But even if we assume for the sake of argument that adjustment of insurance premiums can have an impact on motorist conduct, the quest for super-care is still left with one last difficulty. The aim of general deterrence strategy, it may bear repeating, is an overall net reduction of costs. Super-care may generate offsetting costs.

From the point of view of society, the simple facts are that people can drive too carefully, and excessive care may produce problems of its own. Since the impact on driving habits very likely will be most evident with respect to speed, let us look briefly at the consequences of a widespread but not universal reduction in speed below what is now under the negligence calculus thought to be a reasonable maximum. There is a distinct possibility that this change may work to increase the number of accidents. It is becoming a commonplace that the slow driver on a throughway is as much of a hazard as his excessively speedy brother, largely because his pattern does not mesh easily with that of most drivers, thus resulting in periodic foul-ups of the traffic flow. Moreover, if super-care causes a significant number of drivers to change habits, there will on the average be a general slowing up of traffic. This

37 KEETON \& O'CONNELL, op. cit. supra note 1 , at 252. 
can be counted on to set off a chain of cost consequences, such as loss of time of those being transported or the building of additional roads or the altering of existing ones.

Society of course can always change the speed limits when it is persuaded that slower traffic is more desirable. The puzzle is why we would ever use indirect stimuli to induce people to drive slower than the legal limit. The quest for super-care may, it is true, work better on other aspects of motorist conduct than speed, but we think the analysis has been carried far enough to suggest that there are troublesome problems of offsetting costs to be taken into account. We may in our argument be doing no more than repeating a concern the common law has always had against overinhibiting an activity. ${ }^{38}$ The point is more widely understood in a different context: the overanxious parent is not the model.

We come to the third route through which general deterrence may be expected to operate: the discriminating reduction in the level of motoring. It is probably accurate to say that this represents Calabresi's best hope for general deterrence in the automobile field. In contrast to stimulating safety discovery or to inducing super-care in driving, there is little doubt but that imposing higher charges on motoring will affect behavior significantly. This is simply to say that we have another illustration of the great axiom of economics that price will affect demand. ${ }^{39}$

Calabresi, as we might anticipate, has a more interesting idea in mind than lessening auto accidents by a blunt reduction in the overall level of motoring. He would seek to reduce the level of driving in a discriminating way by forcing the motorist to attend to the distinctive costs of driving under various definable conditions. If, for example, teen-age driving shows a distinctively higher than average rate of involvement in auto accidents, these costs can be placed on such driving by means of differential insurance premiums. We can then expect that "by making more expensive those activities which are accident prone"40 we would discourage them. Presumably under this scheme there would

38 See Seavey, Principles of Torts, 56 Harv. L. REv. 72, 73 (1943).

39 Once again we have an example of inconsistent rationales for a particular rule of law. Consider the rule of liability for ultrahazardous activities. Calabresi's analysis might justify liability without fault as a means of holding down the number of accidents from a given line of activity. Restatement (SECOND), TORTS $§ 520$ (1965), would single out the ultrahazardous activity cases because they involve a risk "which cannot be eliminated by the utmost care." Compare Keeton, Conditional Fault in the Law of Torts, 72 HARv. $\mathrm{L}$. REv. 401 (1959).

40 Calabresi 223. 
be fewer teenagers driving, and consequently costs in the society would be reduced.

This is indeed an attractive prospect. It links legal control to the free market mechanism and thereby achieves its social goals with a minimum of direct restraints on individual freedom and with a minimum of reliance on the political process and majority vote. It accommodates with little friction a wide variety of judgments as to whether the activity remains worthwhile at higher prices. As a matter of affecting behavior it will, we repeat, work.

Insofar as we can follow Calabresi at this point, his thinking runs this way. Under a motorist compensation plan it will be possible for insurance purposes to group motorists into specific categories and to base rates on involvement in accidents regardless of fault. Thus premiums for teenagers will be based on the number of accidents in which teenagers are involved, wholly apart from the number in which they are at fault. This process of dealing with specific subcategories of driving could be extended so long as using smaller breakdowns proved to be feasible. 41

To turn these points into an argument against the common law system and in favor of liability without fault, an important further step is required. It must be shown that this scheme of accident accounting can be exploited to a greater extent under a strict liability system than under a fault system. It is this prospect that we find unpersuasive. Today the differentials in insurance rates are in large measure based on the incidence of involvement and not of ultimate liability due to fault. Further, there is nothing in the nature of things to prevent the insurance institution under a negligence liability law from more fully utilizing such an accounting in setting its rates. The main subcategories in use today-age, urban/rural, sex-are not wedded to fault; and whatever subcategories might be developed under a motorist compensation plan could just as readily be developed today. Hence, all that would be accomplished along these lines by shifting from fault to strict liability would be to increase the total charge placed on motoring but not to place it any more discriminatingly among motorists.

On our view, the argument stumbles over this initial hurdle; never-

41 It might not be easy to combine, in a single strategy of grading insurance premiums, the goal of inducing super-care and the goal of selectively reducing motoring activity. The first goal would seem to call for setting premiums on the basis of accident involvement of the individual motorist; the second, by accident involvement of some class of which he is a member. For example, in dealing with a teenage driver, "super-care" premiums would reward him for staying out of accidents by lowering his costs, while activity repressing premiums would discourage him from driving by increasing his costs because he is a teenager. 
theless, it may be useful to push the analysis a little deeper. Thus far we have been concerned with discriminating among motoring activities solely in terms of seeking to repress those which carry the greater risks of accident - that is, we have been exploring the possibility of maximizing the amount of accident loss reduction for every dollar of "tax" imposed on the motorist.42 One might, however, misunderstand Calabresi to be saying something further, to be suggesting that there may be another dimension to the discrimination he advocates. Is it possible to locate as targets for repression those categories of motoring which are of lesser value to society? It will be remembered that the objective is not simply to reduce accidents, but rather to reduce the net costs of accidents. If qualitative discrimination could be made to work, it would have the benign consequence of holding down the level of accident-producing activity at what would seem to be the lowest offsetting cost. But this happy prospect quickly evaporates upon analysis. There is no likelihood that the driving categories which have the highest accident potential are those which have the lowest social value, as is sufficiently shown by the case of the urban fire engine or police car. In any event, there is no palatable way of ranking driving activity in terms of its social utility. Is driving on weekends less socially useful than driving to work? Undoubtedly some people would be willing to rank the activity for all of us, but we obviously run afoul here of the basic issue of sumptuary legislation. ${ }^{43}$

We are left then, as we compare behavior under the existing system with behavior under the proposed system, with the prospect of an across-the-board reduction in the level of motoring, and a consequent reduction in the overall number of auto accidents. Under these circumstances, whether or not the change-over is desirable turns on weighing the offsetting costs that flow from reducing the general level of the activity. Many are obvious though difficult to trace in any detail. There will be a loss of either work time or leisure time insofar as people shift to slower forms of transportation; there may be an increase in hazard in the more intensive use of some forms of substitute transportation such as car pools or helicopters; there may be increased investment in mass transportation and underuse of investment already committed to auxiliary motoring facilities like garages and parking

42 We ignore here another variable which in principle ought to be considered. Not all subcategories of driving will have the same elasticity of demand. Teenage driving may be riskier, but not as responsive to price changes as other categories of driving. Would general deterrence strategy call for pushing relatively harder on riskier but inelastic categories or on less risky but more elastic ones?

43 For another instance of a latent preference for sumptuary legislation, see the discussion in Blum \& Kalven, The Uneasy Case for Progressive Taxation 68 (1st ed. 1953). 
lots; there may even be a change in driving habits as traffic flows lessen. In brief, this one change will set off a chain reaction of other changes, not all obviously advancing the goal of economizing on resources; and all of these consequences must be taken into account in appraising whether the changeover in liability rules will yield in the end a net reduction in costs to the society. ${ }^{44}$

One of the possible consequences is interesting enough to stop for. In the radium watch example, it will be recalled, we were concerned not only with the conduct of the manufacturer, but also with the conduct of the victim-consumer. Similarly, in the auto case we should look not exclusively at the behavior of motorists, but at the behavior of potential victims (for convenience, pedestrians) as well. Is there any likelihood that changing the behavior of the one will produce any offsetting change in the behavior of the other? More specifically, as we shift all costs off victims in order to encourage super-care in motorists or to reduce the level of motoring, will we be lifting existing restraints on pedestrians, causing them to become more careless or to engage more freely in risky alternatives such as riding motor bikes? We would readily agree that there is a lack of perfect symmetry here. The motorist and the pedestrian are not literally on a see-saw; any legal change on the one that affects his conduct in the desired direction does not necessarily produce an equal change in the wrong direction in the conduct of the other. Nevertheless, in the grand toting up of all pluses and minuses which the general deterrence analysis calls for, we would expect to find some additional costs due to liberating pedestrians to be more careless. ${ }^{45}$

44 The common law has its own formulation. Under the well-known Hand calculus for risk, the law does not shift a loss where the burden or cost to the actor of avoiding the risk of loss is thought, "objectively," to outweigh the cost of the loss. See United States v. Carroll Towing Co., 159 F.2d 169 (2d Cir. 1947). Thus the negligence system might be said to impose liability only where doing so will not result in a net loss. At first glance, it might seem that the common law here has already made the very calculation which interests Calabresi, and that any further imposition of liability beyond the negligence line will result in a net loss to society. But see Calabresi, supra note 4, 78 HARV. L. REv. at 719. The common law formulation looks at a single case at a time and views the economic problem only from the point of view of the particular actor. The economic pluses and minuses for the whole society need not be the sum of the pluses and minuses in all the individual cases. For example, society may legislate a certain speed limit reflecting a judgment that it would be wasteful to insist that every one drive slower. But as Calabresi would argue, it may nevertheless be advisable to impose pressures of general deterrence in order to induce slower driving by some people.

45 It is convenient to note here that coverage of the single car accident under an auto compensation plan-which so greatly troubled the proponents of the Columbia Plan of 1932-is not anomalous under the Calabresi analysis. In the aggregate accounting for society as a whole, it is as important to reduce such accidents as it is to reduce those involving other cars. 
Much of our argument has dwelt on the conjectural aspects of tracing costs, and on the point that Galabresi has not sufficiently persuaded us that a change in liability rules would yield a net reduction in the cost of auto accidents to society. It remains to acknowledge that Calabresi has a major rejoinder to the argument in this posture. And in facing it, we revisit a point we have already partially looked at..6 He argues that the real choice is between a motorist compensation plan of some sort and a social security system, since on political grounds the existing fault system, failing as it does to compensate all accident victims, cannot survive. Then, on grounds of general deterrence, he finds a decisive case for the motorist plan as against social security, regardless of our degree of ignorance about the economic consequences of placing all costs on motorists. As Calabresi puts it: "[A]Ithough it is unclear whether an accident cost is attributable to driving or walking, in terms of general accident deterrence it is better to allocate it to one or the other or both than to pay it out of general taxes.... [W] [here accident costs are not readily divisible between the activities involved, it is clear that placing the costs on them is better than externalizing the costs." $4 \tau$ Since the existing tort system allocates accident costs between driving and walking and does not cover them out of general taxes, this cannot be offered as an economic argument against the present system. Calabresi is staying within the confines of his political prediction that the real choice will be between a motorist compensation plan and social security. We have already noted his rhetorical gambit of offering a political guess under the cover of an economic argument. We look here for a moment at whether the economic argument in its own right is all that good.

In essence, the argument is the comforting one that we cannot go wrong by not externalizing accident costs, however arbitrary and unconvincing our allocation of them between driver and pedestrian may

There may be an additional complication, however. The aim of the law under the Calabresi analysis is to effect the behavior of drivers, including those who are destined to be the drivers involved in single car accidents. Under currently proposed motorist compensation plans, such drivers would, as victims, be assured compensation. The pressures generated by such a law would thus seem to work in opposite directions.

The overlap between those who drive and those who are victims of auto accidents is, as has been widely observed, very great. This fact has caused some to be skeptical whether it can be worthwhile to worry dhout who should pay for auto accident damagethe driver as driver or the driver as victim. See BLum \& Kalven, op. cit. supra note 3, at 43-44. Under the Calabresi approach there may thus be a general problem of offsetting stimuli along the lines of that suggested by the case of the driver who is involved in a single car accident.

48 See text accompanying notes 10-11 supra.

47 Calabresi, supra note 4,78 HARV. L. REv. at 734. 
be. There is no reason to doubt that in terms of sheer numbers, there will be fewer accidents if we do not externalize costs, but instead keep the cost pressures on motorists and pedestrians. The chance of going wrong therefore turns on the offsetting costs. ${ }^{48}$ Putting all costs on motorists runs the hazard of repressing driving so much that the net costs of accidents to society will increase. ${ }^{49}$ There is nothing in the nature of the case that makes it impossible to go wrong.

\section{V}

One trouble with the Calabresi approach is that in a curious way he has been provincial about it all. He has opened legal analysis to broad new horizons, but he has refused, perhaps wisely, to speculate about radically new approaches implicit in his own argument. $\mathrm{He}$ has, if we may risk the phrase, been too tied down to the private law problem without maintaining the appropriate public law perspective.

Calabresi's approach, as we have stressed, has two basic features: he would use net reduction of the costs of auto accidents to society as the criterion by which to judge various measures; and he would utilize, under what he calls general deterrence, the pricing system as a mechanism for controlling behavior.

It might help at this point to rename the game. The objective is to optimize the number of auto accidents by using controls which preserve the maximum amount of individual choice. However jarring it may be to the legal ear to talk of optimizing accidents, this formulation will have a familiar and congenial ring for the economist.

The idea of course is that there is some balance point between the losses from accidents and the offsetting costs of inhibiting the activity. If we fall on one side, we have more accidents than is desirable in the sense that the costs of reducing them are overshadowed by the benefits in cutting losses. On the other side, the analysis makes intelligible the apparently shocking remark that we may have too few auto accidents. What is meant is that the costs of repressing the activity outweigh the benefits.

Calabresi argues that a motorist compensation plan as contrasted to other viable alternatives ${ }^{50}$ will move us further in the direction of

48 The chance of going wrong also depends on the absence of any possibility that the parties involved in accidents can shift the loss through private bargaining. See note $\mathbf{5 3}$ infra.

49 Motorists in effect would be called on to subsidize all others who contribute to auto accidents.

50 Once again it should be emphasized that under Calabresi's analysis there is only one 
optimizing accidents. $\mathrm{He}$ has, however, been willing to play the game only with limited stakes. The dollar magnitudes he wishes to use under a motorist compensation plan to control driver behavior are determined by the number of dollars that will be needed to compensate victims under the plan. As we shall see, there is no likely relationship between the amount of repressant on motorists required to optimize accidents and the amount of compensation needed to pay victims. We may still have too many auto accidents, and thus still be short of the goal. Or, as we have already indicated, the opposite may well turn out to be the case, leaving us with too few accidents.

This line of thought invites readdressing ourselves to the goal of bringing about the optimum number of auto accidents. If we liberate ourselves for the moment from conventional uses of law in the accident area, how might we conceivably arrange matters so as to come closer to that goal? The answer admittedly takes on a science-fiction flavor.

If we were to assume a kind of omniscience giving us full knowledge relevant to auto accident costs-data we clearly do not now havewe could build a mathematical model for stating the optimization problem in precise quantitative terms. Once we reached this stage, there would be no difficulty in solving the mathematical problem thus posed. To set up the model, our omniscience would have had to provide the answers to the following questions: (1) What factors have a bearing on auto accident costs? (2) How should these factors be priced or translated into dollar terms? (3) What is the price curve for each of the factors-that is, how does its contribution to accident costs vary with increases and decreases in its magnitude? (4) How do these curves interact on each other? When the computer finally ground to a halt, it would tell us what pattern of factors would give us the optimum allocation of resources for the auto accident problem. The law would thereby be told exactly where it should be going. The legal problem would then be how best to apply pressures so as to bring about this mix.

In order to leave the widest area for individual choice and to achieve our goal in the most efficient, frictionless way, we would want to use the price mechanism as the control wherever possible. This would call for intruding into the market with taxes or subsidies as conditions required: for example, if optimization called for a certain number of autos on the road, we could, by adjusting the price of motoring up

viable alternative-social insurance paid out of general revenues. And again it should be emphasized that in his view the defect of the common law is not that it fails to move towards optimizing accidents but that it is not politically viable. 
or down, get to the desired number, while leaving to each individual the choice of driving or not. In making these moves no consideration would be given to the compensation of victims. Compensation payments would be made under the social security system, and there would be no need to draw any balance between the "prices" the motorists would pay for driving and the size of the fund required for compensation. The final result would be a perfection of general deterrencea Utopian use of the strategy. ${ }^{51}$

It is worth noting that this fantasy serves among other things to illuminate the meaning of the key phrase, "costs of driving." In our Utopia it is more than possible that the costs of driving will be greater than under any motorist compensation plan. They will, however, be costs of driving in just as valid a sense as they are asserted to be costs of driving under a motorist compensation plan. Since in the auto accident situation costs are instrumental and since there is no way of relying on the market to fix them, they can only be assigned by some authority. For this reason it can never be helpful to talk of placing the costs of driving on driving.

There is no mystery over why Calabresi has not elected to push general deterrence toward Utopia. He tells us explicitly:

$[\mathrm{M}]$ ost important, the world is infinitely more complex than the example. The choice is not between fewer pedestrians or fewer cars. It is among fewer old cars, new cars, cars driven by teenagers and aged ladies, fewer old pedestrians and crippled pedestrians, and all of these in relation to fewer buses and trains and better streets, better street lighting, and so on forever.

In other words, we cannot begin by determining the combination of activities that, given what we consider to be real costs of accidents, brings about the degree of reduction of accidents that we want in the cheapest possible way....

This difficulty, though, is not grounds for abandoning an otherwise valuable approach if partial answers may be discovered and if the partial resolution is better than none at all. ${ }^{52}$

At this point we fundamentally part company. Calabresi urges that despite our deep ignorance in these matters, it is proper in order to implement general deterrence to impose the costs of all auto accidents on drivers, thus in effect adding the costs of non-fault accidents as a

51 Calabresi at this point might well be tempted to invoke the old Hungarian bon mot: "If you have a Hungarian for a friend, you don't need an enemy." He might also come to recognize just how wonderful our world really is.

52 Calabresi, supra note 4, 78 HARv. L. REv. at 732-33. 
tax on driving. The acid test, we suggest, would be a proposal to go further in the same direction by doubling this tax on motorists. We can only surmise that he would be unwilling to take this step. Whether or not he would call it "unfair" to add the surtax, it is our deep hunch he would argue that it was imprudent to do so and that society would risk moving away from optimization of accident costs. Our position is in sharp contrast. We see the reasons for having doubts about the surtax as equally cogent reasons for having doubts about the tax required by a motorist compensation plan.

But perhaps we should not dismiss quite so quickly the possibilities of Utopia. ${ }^{53}$ Putting the problem of auto accidents in terms of the optimization of resources has the special virtue of stating a legal problem in a form which is familiar and congenial to the economist. In this form he can at long last understand what our liability problems are about. It may not be too much to hope that gradually he will find some strands of the problem amenable to his measurements. As one economist has recently observed in discussing the auto accident problem: "To ask an economist how costs should be borne is to ask him what kind of property and social system we ought to have. Give us another 3,000 centuries." 54

\section{VI}

It is time to bring justice back into the discussion. We noted at the outset that Calabresi, finding the idea largely unintelligible, had virtually ruled it out as a goal for the legal system. And in so doing he was echoing the views of fellow economists who would distinguish sharply between justice and economic efficiency as guides to social policy. We stumble here upon what we suspect is a fundamental issue which goes well beyond auto compensation. There are various ways

53 In the eyes of the bar another Utopian approach to the auto accident problem coming from economics would be an effort to adopt the general analysis offered by Ronald Coase. The Coase approach would seek to minimize the difference between cases like our radium watch dial example, and auto accident cases where there is no market nexus between the parties. He has succeeded in demonstrating that some cases, always thought of as outside the market, can be treated as market situations if the parties are in a position to strike private bargains as to paying for the cost of injuries resulting from an activity-as in the instance of the example he utilizes involving cattle raisers and crop farmers. See Coase, The Problem of Social Costs, 3 J. L. \& Econ. I (1960). As far as we can see, the relationship between the parties involved in auto accidents is too remote from any conceivable bargaining arrangement to make this analysis usable. Calabresi seems to agree. See Calabresi 231-32. See also BLum \& KaLven, op. cit. supra note 3, at 61-62; Demsetz, supra note 1 .

54 Alchian, Review of Public Law Perspectives on a Private Law Problem, 34 Gro. WASH. L. REv. 820, 823 (1966). 
in which the basic query may be put: Is there any meaning "left over" for justice once efficiency goals have been attended to? Can efficiency ever conflict with justice?

Whatever the full range of such questions, they are vividly framed by the controversy over general deterrence and the auto accident. If society is coercively to impose a burden on citizens, we submit that there must be some justification for imposing it on one group rather than another. In this context we mean by justice the avoidance of what will be perceived as an arbitrary imposition of a burden.

The difficulty with general deterrence as a justification for shifting non-fault auto accident losses to motorists is that it is too fragile to carry the weight that would be put on in. Where the burdens are clear, certain, and not trivial, something more than conjecture about possible patterns of behavior is needed as a countervalue. To put the disagreement in a nutshell: when we know as little as we appear to know now about the prophecies of general deterrence, it is unjust to tax motorists on behalf of it..$^{55}$

A more critical difficulty turns on the relative magnitude of the gains and the burdens involved. Let us assume that we know enough to devise a general deterrence strategy and to put it into operation, and that when it is implemented there will at the end of the year be an increase in the gross national product of $\$ 1000$ as a result of a reduction in the net costs of auto accidents by that amount. Let us assume further that to achieve this social good it is necessary to levy an additional tax of $\$ 100$ on each motorist. We pick an example as extreme as this in order to raise a key question: Is there not some point at which even an unqualified gain in the efficient allocation of resources, achievable only through this particular route, is not of sufficient importance to justify the burdens which it calls for placing on particular individuals?

Although we recognize that the most rigorous and austere economic analysis might insist that the answer is no, we are quite confident that most people, and especially those in the traditions of law, would say that the answer must be yes. We therefore have a final difficulty with the Calabresi thesis. Even if we are to resolve all doubts in favor of the ability of a general deterrence strategy to bring about a net reduction in the costs of auto accidents, we may still confront a disturbing imbalance between the social gain achieved and the individual burdens imposed. Where the social gain seems small and the individual burdens in the aggregate seem relatively large, we find ourselves think-

65 Put another way, it is unjust not also to tax others who contribute to the accidents. 
ing of the dangers of reversing Churchill's famous epigram: "Never have so many owed so much to so few." If we were to put our reaction into somewhat less personal terms, it would be that there very likely are hidden values that cannot be translated into economic costs, such as the value of having individuals understand why they are being subjected to a special tax and the value of not departing too lightly from traditional and accepted ways of doing things. ${ }^{56}$

\section{VII}

In concentrating on Calabresi and the theory of general deterrence, our discussion of the auto compensation problem admittedly has been badly skewed. ${ }^{57}$ We have singled out his writings not only in retaliation, but also because we have found his analysis to be most intellectually stimulating and the most promising for general tort theory. The fact of the matter is, however, that the auto accident problem is being widely discussed and that general deterrence has not been salient in the recent literature. ${ }^{58} \mathrm{~A}$ review of recent developments is not now in order. But there is one feature in current thinking about auto plans that clamors for a further word. Turning to it will serve to move this essay toward a close.

The dominant view today among proponents of compensation plans is that the plans should be what might be called "two level." Originally, as in the Columbia Plan of the early thirties, the idea was to replace the tort system for auto accidents in toto with a compensation scheme. The new view is to provide an underlying plan that will compensate all victims but only up to some ceiling level of awards; and to leave

56 In the science-fiction world discussed in part $V$, it would be "possible" to avoid the difficulty noted here by collecting the special tax simply as a way of controlling the behavior of those individuals in the class of motorists, and then refunding that same aggregate amount to the class on a per capita basis out of general revenues. The class would not be worse off financially, thus exasing our difficulty as to the imbalance between burden and gain. Some motorists would be better off and some worse off; for example, the special tax on teenage motorists might exceed their share of the per capita "repayment" out of general revenues.

57 Other reasons being advanced for adopting a motorist compensation plan are at very different levels. These include: (1) reducing the amount of fraud associated with proving fault; (2) reducing the size of legal and other fees in pressing a claim; (3) reducing the congestion of courts in various metropolitan areas; (4) providing prompt compensation for needy victims; (5) simplifying the handling of insurance and thereby reducing the cost of insurance; (6) reforming the present structure of damage awards. Proponents of plans have weighed these factors differently.

58 Perhaps a sufficient indication of this is the attention paid by Keeton and O'Connell to Green, to Ehrenzweig, to Morris and Paul, to Conard-and to Blum and Kalven, as contrasted to their single footnote reference to Calabresi. KEETON AND O'ConNELL, op. cit. supra note 1, at 259. 
the existing fault system alive while abolishing the collateral benefits rule, under which welfare payments could not be deducted from damages in tort suits. ${ }^{59}$ The result is two levels of compensation: automatic but limited compensation to all victims, plus unlimited compensation to victims who can establish a fault basis for recovery. ${ }^{60}$

A first reaction might well be that such arrangements are politically ingenious but wholly unprincipled. The absence of clear principle is suggested by twin circumstances: the proponents have argued the need for a compensation plan on the weaknesses of the common law fault criterion and have viewed some aspects of common law damages as excessive; they nevertheless end up by keeping the fault system alive and giving common law damages. ${ }^{61}$ The cleverness of the arrangement is that it makes possible a plan under which no victim as a victim can be worse off than he was at common law and under which some function is still left for the tort system. Thus any sense of grievance over the proposed change is abated for those parties most likely to complain -the victims and the lawyers. ${ }^{62}$

On fuller examination, however, it appears there need be no inconsistency in the two level arrangement; and further, whatever the practical motivation for such plans, the two level concept may be the route to a sound solution to the whole problem. The key lies in the separation of two functions of tort damages that have always been tied together in the past-the welfare function of providing relief for the

59 The collateral benefits rule states that where an accident loss is compensated by insurance proceeds, employment fringe benefits, or outright gifts by a third party, the law will treat such payments as coming from collateral sources and therefore as not relevant to the computation of damages.

60 The clearest instance of this two level approach is the Saskatchewan Plan. See GREGORY \& KALVEN, CASES ON TORTS 757-60 (1959). Another instance, although a more complicated version, is that in KreTON \& O'CONNELL, op. cit. supra note 1, at 273.

61 These inconsistencies are frequently raised in bar association discussions in criticism of the Keeton-O'Connell Plan. See, e.g., Green, Basic Protection and Court Congestion, 52 A.B.A.J. 926 (1966).

62 A distinctive aspect of the Keeton-O'Connell Plan is that it deliberately leaves some victims worse off and thus does not follow the strategy of the Saskatchewan Plan. The principal loss of rights are the elimination of the first $\$ 5000$ of damages for pain and suffering; the elimination of the collateral benefits rule for most claims; the elimination in many cases of wage losses in excess of $\$ 750 \mathrm{a}$ month; the elimination of the first $\$ 100$ of any loss (which is borne by the victim). See Marryott, The Tort System and Automobile Claims: Evaluating the Keeton-O'Connell Proposal, 52 A.B.A.J. 639 (1966). Marryott concludes that as a result of these provisions "in a state like New York 80 per cent or so of the basic protection claimants will have their benefits substantially reduced, [and] the net effect is that a large majority of the persons injured in automobile accidents will be looking to non-basic protection benefits (self-provided, government-provided, employer-provided) as the principal sources of reparation for automobile accident injuries." Id., at 642. Compare Blum \& KaLven, op. cit. supra note 3, at 32-40. 
injured and the corrective justice function of righting a private wrong. So long as the functions are lumped together, the welfare function is likely to be seen as dominant given presest concerns. By separating the functions, the two level plans may test sharply whether the corrective justice function is worth preserving.

In our earlier essay we found it instructive to think about the tort field being overlaid by the adoption of a broad social security system that covered a large variety of human ills and misfortunes. And we maintained that, insofar as we are concerned with compensation of victims, there is no alternative superior to extension of social security. It alone can provide a coherent and equal treatment of deserving beneficiaries, and it alone is capable of furnishing a rationale for distributing burdens and for determining benefits. What the two level plans ultimately put in issue is whether even under such extensive welfare guarantees there is a function left over for the tort system. ${ }^{63}$

The answer is not without its difficulties. There are two wings to the problem: the case for corrective justice with respect to accident injuries that fall below the ceiling for social security payments, and the case for it in the more serious accidents. The two level plans that are now being offered preserve the tort function in the more serious accidents but eliminate it in the less serious.

This handling of the less serious accident cases is probably inescapable, but it is worth working through the analysis. There are three possibilities that merit consideration: the victim can recover only from the welfare fund, but the fund can recover over from the tortfeasor; the victim can recover both from the fund and from the tortfeasor; once the victim has recovered from the fund, neither he nor the fund can recover from the tortfeasor. In this matrix the problem has been thoroughly analyzed elsewhere by others, and there is no need to restate it here. ${ }^{64}$ One point, however, is of special interest to us. In large part corrective justice is concerned not with deterring the wrongdoer, but with satisfying the victim's feeling of indignation. ${ }^{65}$ If the victim recovers only from the fund, he will not gain the satisfaction of seeing

63 As a matter of history, the English reached this issue when they adopted the Beveridge national welfare plan which provided for broad social insurance. The proposal precipitated wide debate on whether to abolish the tort remedy altogether or to abolish the collateral benefits rule with respect to the welfare plan payments. The English "solved" the problem by doing neither. See Friedman, Social Insurance and the Principles of Tort Liability, 63 HARv. L. REv. 241 (1949).

64 See James, Social Insurance and Tort Liability: The Problem of Alternative Remedies, 27 N.Y.U.L. REv. 537 (1952).

65 Compare Aristotle, Nicomachean Ethics V (iv) (Loeb transi. 1926); Hart, The CONCEPT OF LAW 160 (1961). 
his wrong righted. Nor will it be much different if, after paying the victim, the fund later recovers from the tortfeasor. We come then to the question of whether it is worth allowing the victim to have a double recovery merely to satisfy his sense of indignation-with the tort recovery becoming in effect a form of punitive damages.

Several reasons converge on the conclusion that double recovery would be unwarranted. To leave the victim with his tort action in addition to his social security payments would be to continue to burden the adjudication system with all the costs today associated with litigation and settlement. Inasmuch as motorists would continue to run the risk of tort liability for negligence, the demand for liability insurance would be little changed, and hence there would be the cost of keeping the insurance arrangements alive. Moreover, because of the presence of insurance the corrective justice lesson would be lost in many cases on the tortfeasor; often he might never even learn how the case came out. ${ }^{66}$ Nor in allowing a double recovery can we ignore the traditional view that punitive damages in any form are not appropriate for negligent conduct. Finally, there is the telling point that the double recovery is likely to spoil the corrective justice adjustment from the viewpoint of the victim as well. Since he has been made whole by the social security payments, he is apt to perceive the tort recovery more as a windfall than as the correction of a loss wrongfully caused.

But do the arguments change when we shift attention to the more serious injuries-those in which the social security payments are not thought to make the victim whole? Only one point is really different. To withdraw the tort remedy in this context would be to leave the victim with some uncompensated loss wrongfully caused him by another. Conversely, to give him a remedy would be perceived as correcting a wrong and not as a windfall. The tort remedy can thus serve to satisfy his sense of moral indignation.

Undoubtedly people will weigh these arguments differently. Many are likely to hold to the view that the vagaries of the fault criterion, the costs of litigation and of insurance arrangements, the obscuring of corrective justice adjustments because of liability insurance, and the oddity of pain and suffering as damages all combine to make the game not worth the candle. ${ }^{67}$ There is assuredly much to be said for striking the balance this way, but we would conclude otherwise.

o6 Conard, Morgan, Pratt, Voltz, \& Bombaugh, op. cit. supra note 1 , at 296-99. Included in their elaborate survey of some 86,000 accident losses were questionnaires to a sample of 183 insured defendants. In $33 \%$ of the cases the defendant did not know whether the claim against him had been paid or not; if, however, the case went to trial, only $5 \%$ of the defendants remained unaware of the outcome of the claim.

07 The opponents of plans have frequently asserted that a two level arrangement, by 
To us there remains great force in the notion that no one should be worse off because of the wrongdoing of another so long as the wrongdoer, or his insurer, is in a position to make redress. ${ }^{68}$ The law ought not to break sharply with the moral traditions of the society, as it would do were it no longer to recognize fault and personal responsibility. And we would urge that not all reflection of moral values should be left to the criminal law. The tort system can share some of the burden of satisfying indignation.

The two level arrangement, whereby welfare underwriting for all accidents is supplied by social security and the tort system is left "on top" of that underwriting, has one paramount advantage. It permits the society to make independent judgments on matters that cannot be cleanly handled together-the setting of welfare payment levels and the setting of corrective justice damage levels. ${ }^{69}$ On the one side, welfare payments should be set by some general standard deemed appropriate for victims of all misfortunes. They clearly should not be set differently for victims of auto accidents and other victims. And they should, as a matter of policy, be set without contagion from common law damages and the settlement practices of insurance companies. On the other side, it should be observed that there is a basic compatibility between pain and suffering as a recognition of the dignitary aspects of accident injuries and a liability system keyed to fault. From a welfare point of view awards for pain and suffering may well be regarded as a quixotic luxury; from a corrective justice point of view such damages may be at the heart of the matter. ${ }^{70}$

\section{VIII}

By a curious route we are led back to Calabresi and general deterrence. We earlier showed that Calabresi is much too sanguine that a

its victim protection underwriting, will serve to finance tort suits, and that this will have a very undesirable effect on claims consciousness and on court congestion. On the other side, it has been suggested that once the urgency of compensation is satisfied by victim protection, pressure will be taken off the tort system to expand the concept of fault. The assumption is that if the tort system had to serve only a corrective justice function, the fault criteria could be kept narrow and pure. See EhrenzwEIG, "Full AID" Insurance FOR THE TRAFFic Victim (1954).

68 We would take this position even if insurance premiums remain as undifferentiated as they are now. But any increase in differentiation probably would increase the perception that corrective justice is being done.

69 See Blum \& Kalven, op. cit. supra note 3, at 36-39. Compare Calabresi's discussion of what is "appropriately" a cost of an accident. Calabresi, op. cit. supra note 4,78 HARv. L. REv. at 721-24.

70 This view suggests a solution to the dilemma which Jaffe argued the tort system faced as it sought both to "honor" pain and suffering and to compensate ever more widely. See Jaffe, Damages for Personal Injury: The Impact of Insurance, 18 LAW \& CoNTEMP. Prob. 219 (1953). 
motorist plan will move in the direction of optimizing auto accident costs, but we have not examined fully ${ }^{71}$ his position that social security is from a general deterrence viewpoint the worst of all possible worlds. We turn to it now.

Once again Calabresi seems to have narrowed his sights too much. It is by no means true that the welfare objective must be satisfied in a form which externalizes accident costs. In our society it is becoming less and less utopian to think of adopting a social welfare system under which payments would not be for specific items, but rather would be calculated to provide everyone with a minimum level of annual income, out of which individuals would be free to insure themselves against catastrophic losses. ${ }^{72}$

As a final twist of the analysis of the auto problem, let us posit for a moment a "two level" plan under which the social welfare underwriting would be in this form and all accident losses due to fault would remain actionable under tort law. Such a regime might well rank highest even under Calabresi's point system. It would provide for all needy victims; it would maximize the range of individual choice; it would satisfy the demands for corrective justice; and most important, it would not externalize any auto accident $\operatorname{costs}^{73}$ It would, moreover, have the added feature of eliminating all questions about overlaps between payments under the tort system and under the social welfare system. Victims of fault losses would continue to recover their losses in full from the tortfeasors or their insurers. Welfare payments would be made to adjust for inadequacies of income and not for particular accident losses. Neither these losses nor the compensating payments would be counted in determining the right to welfare payments pursuant to the minimum income schedules.

But would this regime be "fair" to the victim of a non-fault accident who was unable to recover anything for his loss? To us the answer is clearly yes. We find that his case for recovery is no more (and no less) appealing than those of the victims of other misfortunes, including being born badly handicapped or having a heart attack or being struck by lightning. The answer becomes even more persuasive when we ask ourselves whether we would allow the victim of a non-fault accident to shift his loss if everyone had ample economic means. Once we are freed of concerns about poverty, is there any case for compen-

71 Earlier we suggested that placing all additional costs on motorists might be worse than externalizing them. See note 49 supra and accompanying text.

72 See Friedman, Capitalism and Freedom (1962).

73 It does not externalize non-fault accident costs because they are left on the victim. If the victim is entitled to receive welfare payments, it is because he is poor and not because he was injured in an auto accident. 
sating victims of misfortune apart from working corrective justice in redressing humanly caused wrongs?

In these reflections we have explored a continuum encompassing four solutions to the auto accident problem: the common law fault liability system; a two level plan consisting of a tort action for fault on top of non-fault compensation to all victims, financed by motorists; a two level plan, this time with the non-fault underwriting provided by social insurance that covers a wide range of misfortunes and is paid for out of general revenues; and finally, a two level plan in which there is no underwriting for specific misfortunes but a general underwriting of income up to some level. Two points should be emphasized. Under all four alternatives for solving the auto problem, the fault system remains alive, albeit only for some purposes. And while the most obvious difference is between the common law system and the two level arrangements, we would urge that the differences among the two level arrangements are also critical. ${ }^{74}$ Against this backdrop, it may be useful to once more summarize the basic position we have been advancing in these essays.

The tort system should be kept alive for auto accidents not as a compromise to make change politically palatable, but because it has a distinctive function to perform in the handling of indignation. Insofar as society is being moved by the needs of uncompensated victims of auto accidents, the law should group the beneficiaries of its intervention rationally and should not single out the auto victims for preferential treatment; better still, it should address itself directly to the problem of poverty. The award levels should be set in terms of the function being performed by payment: welfare awards should be keyed to general welfare criteria, and damages for being wronged should permit recognition of indignation. Finally, the method of financing awards should also be selected in terms of the functions being performed by the payments. General welfare payments should be financed from general taxes, ${ }^{75}$ and corrective justice payments should be assessed against those guilty of flawed conduct.

74 Two "political" points have been raised against the position that if welfare is the goal, social security and not a motorist compensation plan is the appropriate route. On the one hand, it is argued that a motorist plan is a halfway house on the road to social security; on the other hand, it is argued that since adequate expansion of social security will never be forthcoming, half a loaf is better than none. It should be clear from the text that we are hopeful that it is possible to separate one's policy judgments from one's political predictions. Indeed, a chief objection to the Calabresi analysis is that he has failed to do so.

75 There may even be a few problems of distributive justice in this area. See, BluM 
There has been a good deal of development of the topic in the two years since we first attempted to think through the auto compensation problem. Important new research has been published; thoughtful legislative proposals have been made; Calabresi has advanced the analysis of general deterrence; and there has been much debate in the law school world and in bar forums. As a result, we have had occasion to reexamine, to restudy, and repeatedly to adjust our position to new insights. There is, however, a sentence about motorist plans that seems to us as pertinent now as it did two years ago. The sentence will come as a surprise to no one, and we end with it. "If the expanded coverage in operation will cost more than the present system, what justification is there for placing such additional costs on those who own or operate vehicles?"76

8. Kalven, The Uneasy Case for Progressive Taxation (1st Phoenix ed. 1963). Afficianados of this issue might be interested in the reports of the American Institute of Legal Jurimetrics, published in 43 TAXEs 636 (1965) and 44 TAXEs 737 (1966).

76 BLUM \& KALVEN, op. cit. supra note 3, at 54. 